\title{
دقالم يَرْوهشى
}

\section{اثر محروميت از خواب بر ياسخ تستوسترون و كورتيزول سرم بدنبال فعاليت هوازى}

\author{
محمدرضا رئيسى '، ناصر بهيور '، احمد همتفرَّ، ميرزا حسين نوروزى كمره
}

'كارشناس ارشد فيزيولوزى ورزشى، دانشكاه آزاد اسلامى واحد بروجرد، بروجرد، ايران

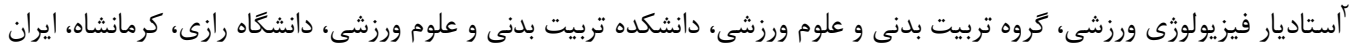

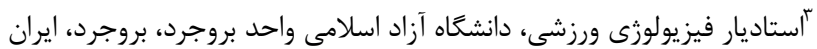

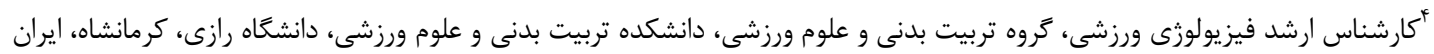

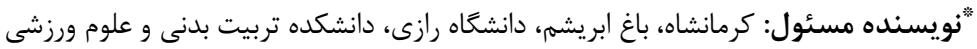
:

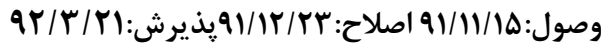

جكيده

زمينه و هدف: خواب فرآ يندى بهبود بخش براى سيستم عصبى است. موقعيتهاى زيادى وجود دارد كه قبل از فعاليت ورزشى، ورزشكار

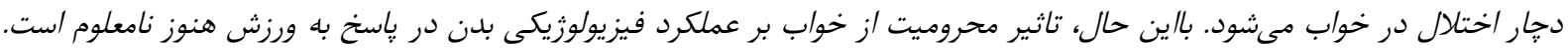

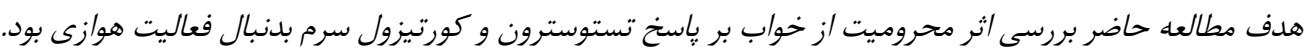

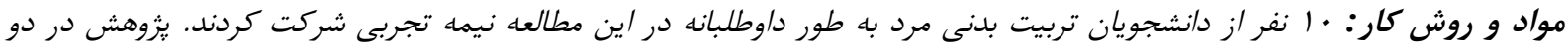

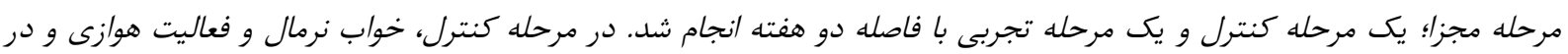

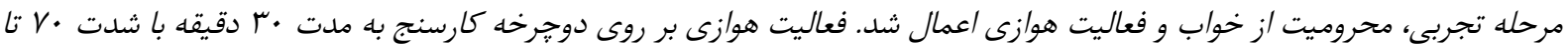

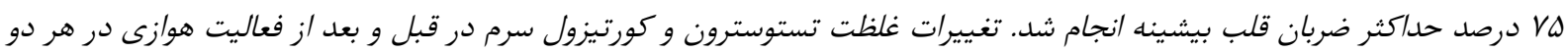

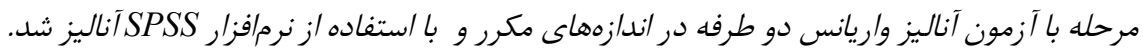

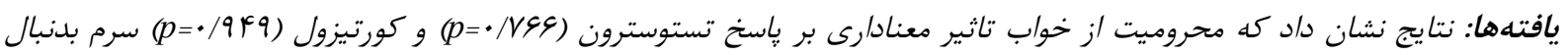
فعاليت هوازى ند/شت. نتيجهكيرى: محروميت از خواب تاثير بر باسخ غلظت تستوسترون و كورتيزول سرم بدنبال فعاليت هوازى زير بيشينه ندارد.

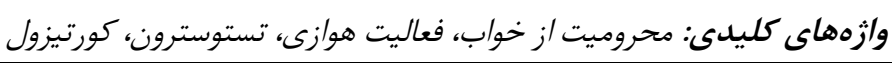

سيستم قلبى - عروقى داشته باشد و خطر بيمارىهاى قلبى - عروقى را افزايش دهد [ب]. نشان داده شده است

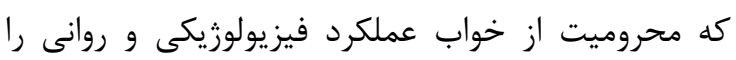
تحت تاثير قرار مىدهد [[]]. اگرجه ورزشكاران و مربيان معتقد هستند كه خواب كافى براى عملكرد بيشينه ضرورى است ولى موقعيتهاى زيادى وجود دارد كه قبل

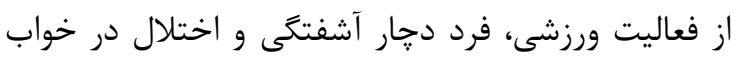
مىشود، براى مثال، ورزشكاران به دلايل مختلف مثل مسافرت براى انجام مسابقات ورزشى و يا اضطراب و مورئ استرس و تحمل فشار روانى در شب قبل از مسابقه، ممكن

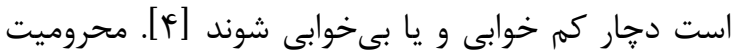

خواب يك فرآيند بهبود بخش براى سيستم عصبى است.

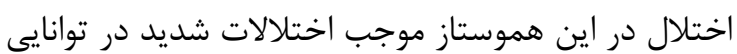

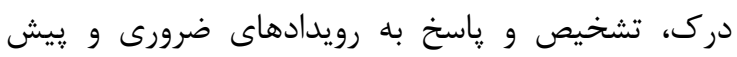

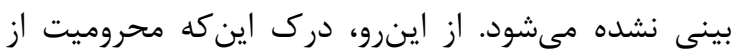

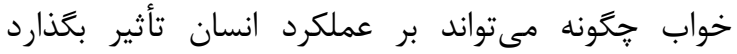

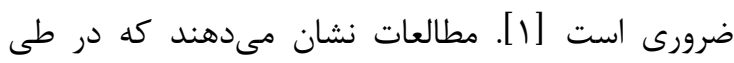

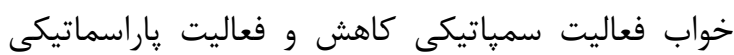
افزايش مىيابد. اين تغييرات باعث كاهش ضربان قلب و فشار خون شبانه مىشود. بنابراين، محروميت از خواب طولانى مدت ممكن است به طور مستقيم تاثير منفى بر 


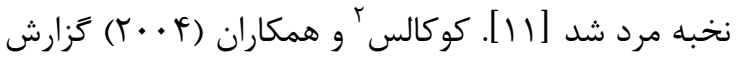
كردند كه تمرين هوازى در قايقرانان نخبه موجب افزايش

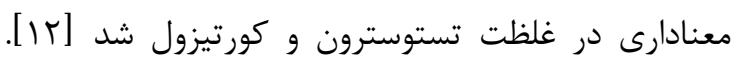

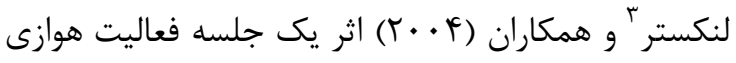

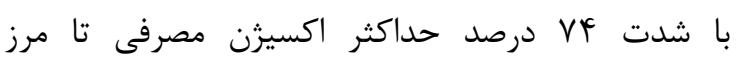
خستگى بر غلظت يّلاسمايى كورتيزول را در دوخرخه

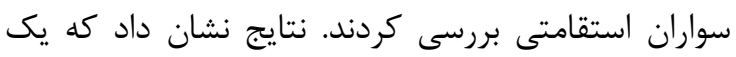

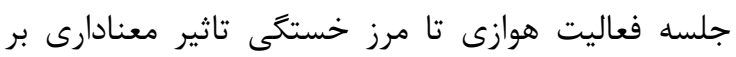

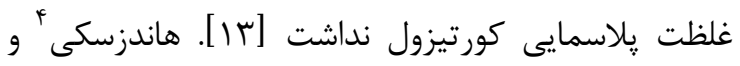

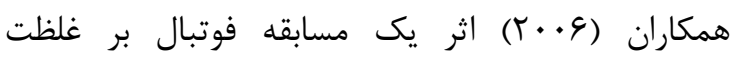

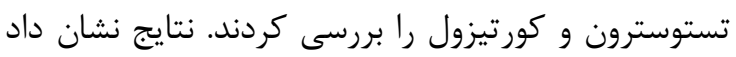
كه غلظت تستوسترون به طور معنادارى افزايش يافت،

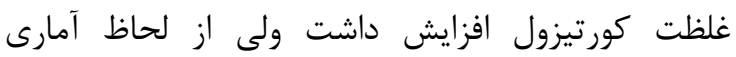
معنادار نبود [1 [1]].

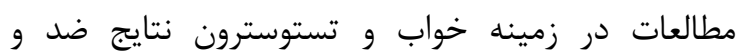

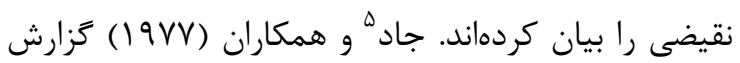
كردند كه در طول خواب نسبت به بيدارى ميزان ترشح

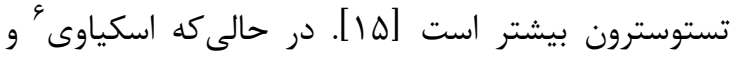

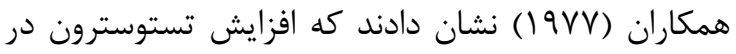

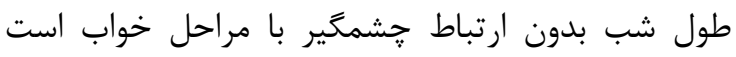

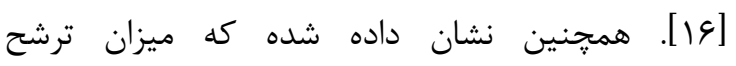
تستوسترون در نتيجه محروميت از خواب كاهش مى يابد.

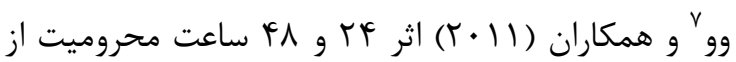

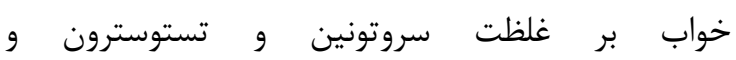
كورتيكواستروئيدها را در رتهاب نوان جوان بروسى كردند.

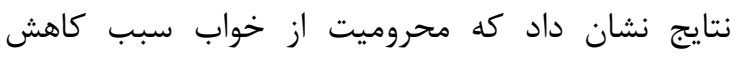

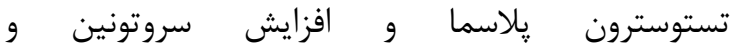
كورتيكواستروئيدها مىشود [IV] برخى از مطالعات نشان دادهاند كه محروميت از خواب

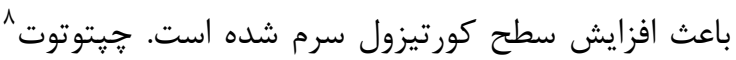

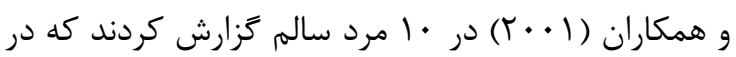
طى شب محروميت از خواب غلظت يلاسمايى كورتيزول

\section{2 - Kokalas}

3 - Lancaster

4 - Handziski

5 - Judd

6 - Schiavi

$7-\mathrm{Wu}$

8 - Chapotot
از خواب به عنوان روشى براى مطالعه اختلالات خواب

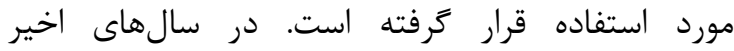
محروميت از خواب يكى از رايجترين مشكلات سلامتى

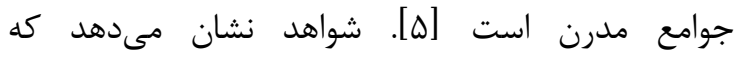
ورزشكاران در رابطه با اثرات خواب ناكافى بر عملكردشان

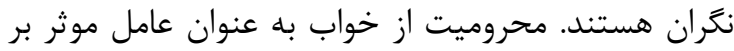
ارتباط اضطراب-عملكرد ورزشى، كمتر مورد توجه قرار كرفته است [ع]. در حالى كه محققان از ميزان خواب إنداب

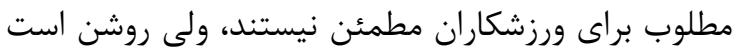

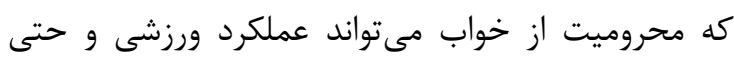

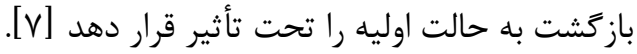

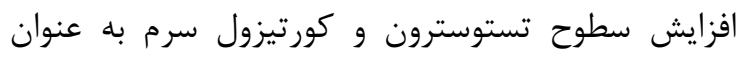

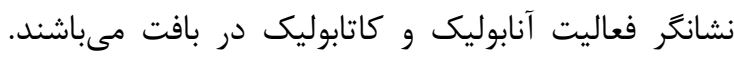

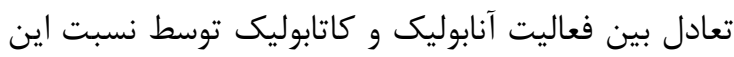

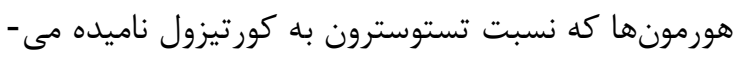

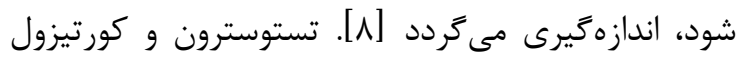

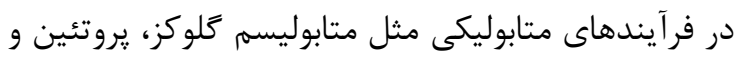

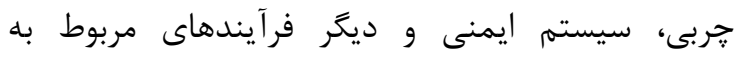
هموستاز بدن كه تأثيرات زيادى بر عملكرد ورزشى بدن دين فرين

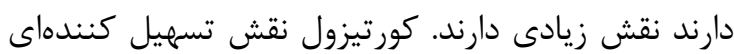
در برخى از فرآيندهاى حياتى بر عهده دارند دارد. اعمال كورتيزول در رابطه با فعاليت ورزشى عبارتاند از تجزيه كاتابوليكى يروتئينها و اعمال ضد التهابى. عملكرد مهرم خونى ديكر كورتيزول حفظ فشار خون و حجم يلاسئا

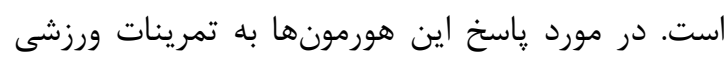

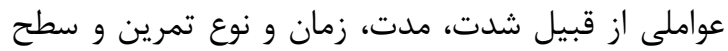

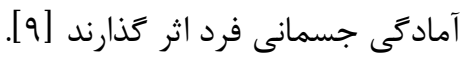

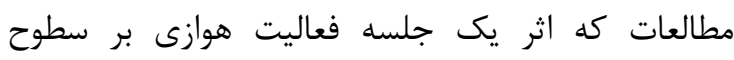
كورتيزول و تستوسترون را بررسى كردهاند نتايج متفاوتى را كزارش دادهاند. عطار زاده حسينى و همكاران (r (T) كزارش كردند كه يك جلسه بازى فوتسال در بادئن بازيكنان فوتسال نخبه باعث افزايش غلظت تستوسترون و كورتيزول بكان باري

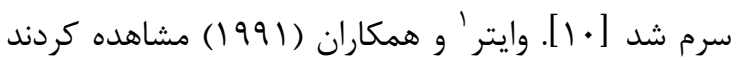

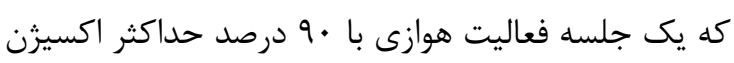
مصرفى سبب افزايش سطوح كورتيزول در ورزشكاران

1 - Wittert 
يرسشنامه اطلاعات فردى توسط آزمودنىها تكميل شد. فرم رضايت نامه كتبى از همه آزمودنىها كرفته شد. ابتدا كل يروتكل براى آزمودنىها شرح داده شد تا با اهداف آنداف آنداف

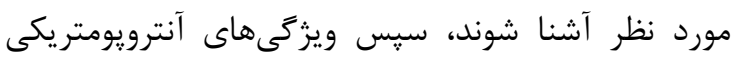
بدن مثل قد، وزن و درصد جربى بدن افراد ثبت شد شدائ (جدول (). يزوهش در دو مرحله مجزا، يك مرحله كنترل

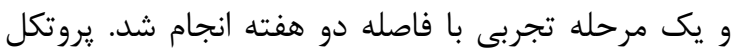

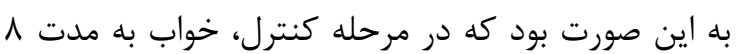
ساعت اعمال شد و در مرحله تجربى به فاصله دو هفته

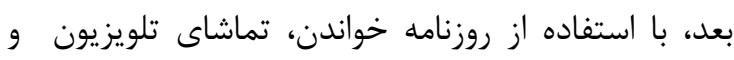

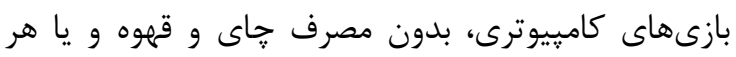

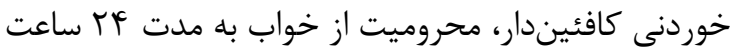

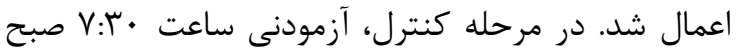

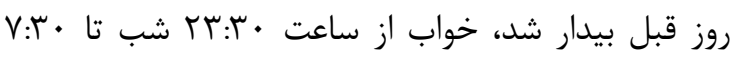

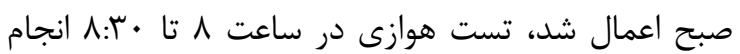

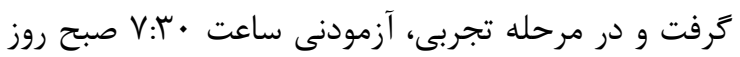

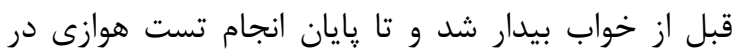

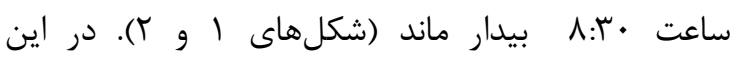
يزوهش در هر مرحله سه بار نمونه خونى گرفته شد به اين آنائ

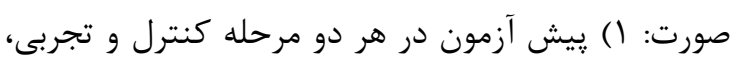

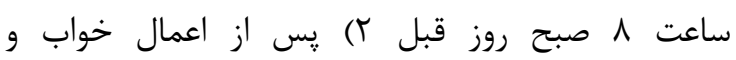
محروميت از خواب در دو مرحله تجربى و كنترل، در

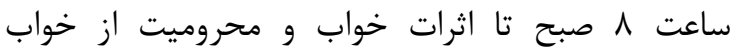

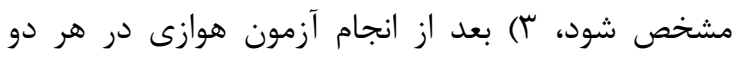

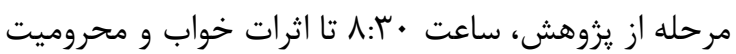
از خواب در ياسخ به فعاليت هوازى مشخص شود. بنابراين در اين يزوهش در هر دو مرحله شش بار نمونه خونى بـ باني كرفته شد. سه روز قبل از انجام هر مرحله از يزوهش، به همه آزمودنىها دستور غذايى يكسان داده شد. در آند مرحله

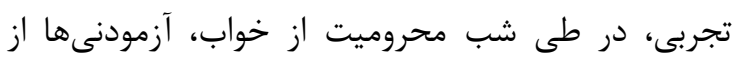

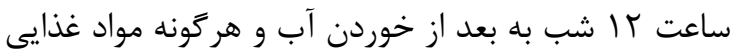

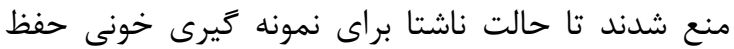

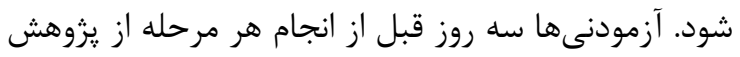

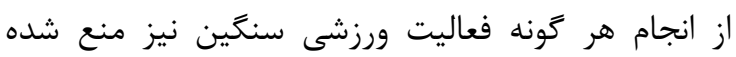

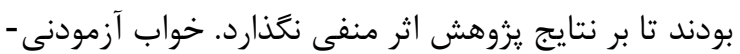

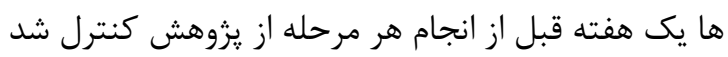

افزايش مىيابد [1/]]. همجنين ليرولت' و و همكاران (1997) جوان سالم بر غلظت كورتيزول سرم را بررسى كردند و

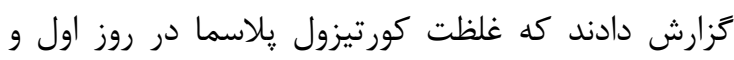
دوم محروميت از خواب به خصوص در عصرها به طور

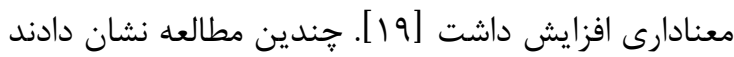
كه محروميت از خواب تاثيرى بر سطوح كورتيزول ندارد.

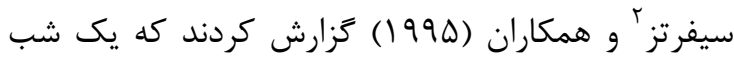
محروميت از خواب در مردان سالم تاثيرى بر غلظت

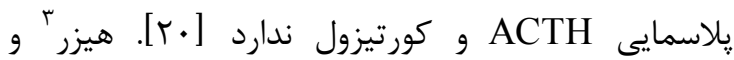

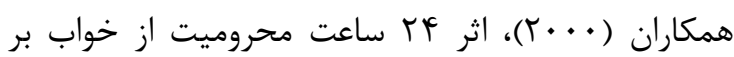
كورتيزول بزاقى را بررسى كردند. نتايج نشان داد كه آنا غلظت كورتيزول بزاقى از لحاظ آمارى تغيير معنادارى

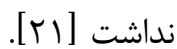
موقعيتهاى زيادى وجود دارد كه قبل از فعاليت ورزشى، ورزشكار دجار اختلال در خواب مىشود، با اين حال، تاثير

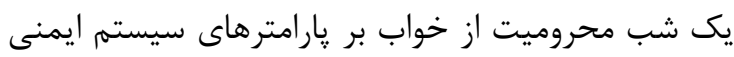

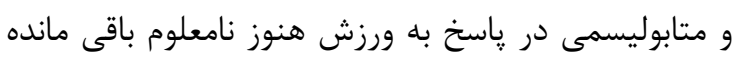
است. از آنجايى كه سلامتى و افتخار آفرينى ورزشكاران در مسابقات برون مرزى يكى از مهمهترين دغدغههاي إنى

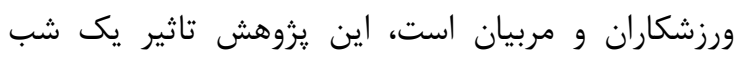

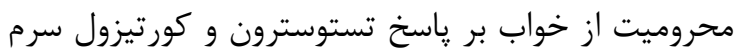
بدنبال فعاليت هوازى را بررسى كرده است. نتايج يزوهش

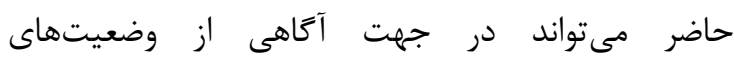
فيزيولوزيكى ورزشكاران نسبت به محروميت از خواب موثر

يزوهش از نوع نيمه تجربى بوده كه داراى جنبه كاربردى

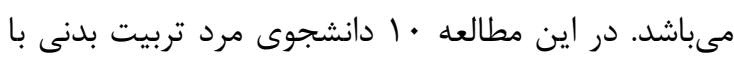

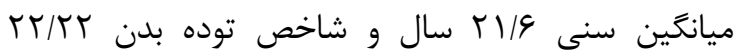

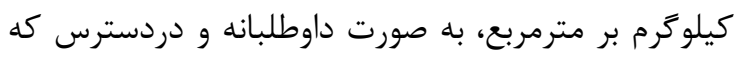

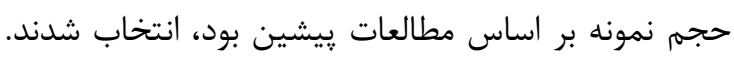

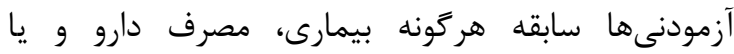

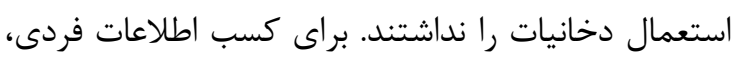

1 - Leproult

2 - Seifritz

3 - Heiser 


\begin{tabular}{|c|c|c|c|c|}
\hline \multicolumn{5}{|c|}{ جدول ا: ويزگَىهاى توصيفى آزمودنىها } \\
\hline حداكثر & 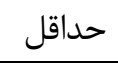 & انحراف استاندارد & ميانگين & \\
\hline$r F /$. & $r \cdot / \cdot$ & $1 / \cdot V$ & TI/G. & سن(سال) \\
\hline $195 / \cdots$ & $199 / \cdot$. & $\Leftrightarrow / \Delta \Delta$ & $I V V / D$ & قد(سانتىمتر ) \\
\hline$V \wedge / 1$. & $\Delta F / \Delta$. & $v / \mu^{\prime}$ & $99 / 91$ & 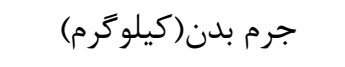 \\
\hline$r \Delta / \cdot$ & $19 / 1$ & $r / \cdot \cdot$ & TT/Tt & شاخص توده بدن(كيلوگرم \\
\hline & & & & بر مترمربع) \\
\hline $\mid \varepsilon / 4$ & $\varepsilon / 9$. & $r / \Delta \Lambda$ & $1 \cdot 190$ & در صد جربى \\
\hline
\end{tabular}
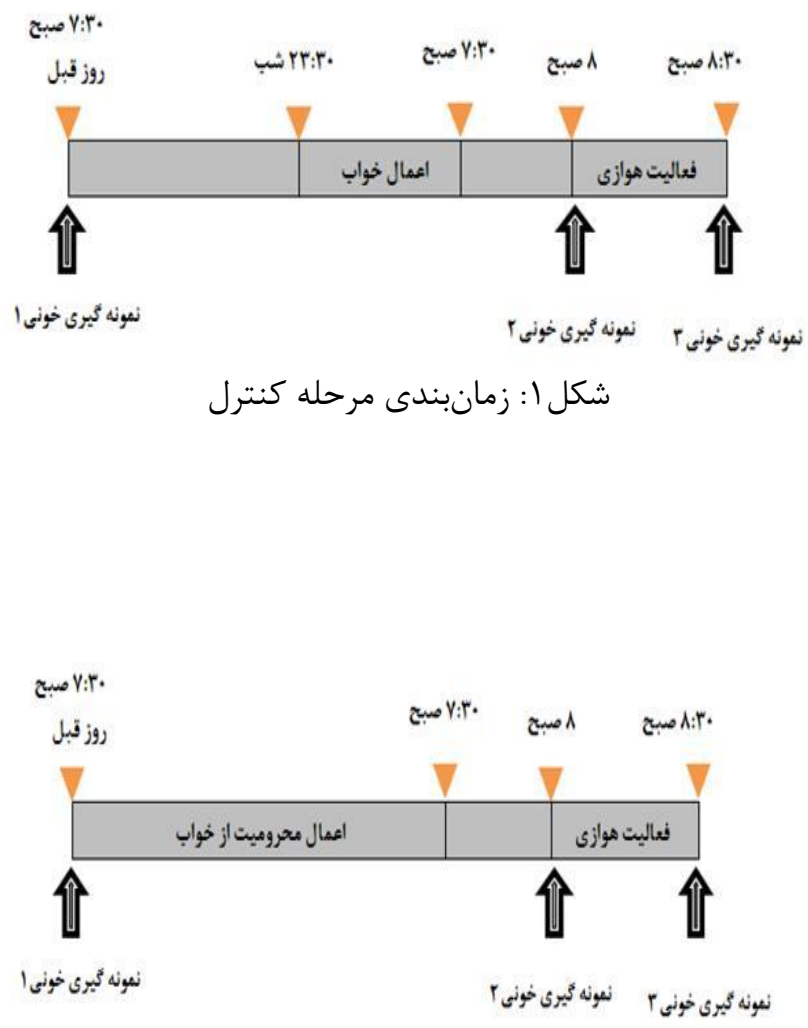

شكل r: زمانبندى مرحله تجربى 
نتايج ييشآزمون و يسآزمون در هر مرحله از يزوهش

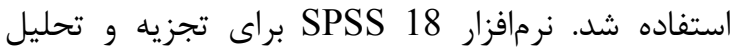

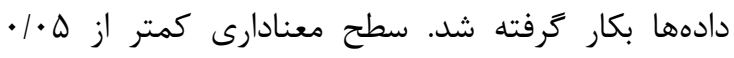

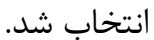

يافتهها

ميانگين و انحراف استاندارد غلظت تستوسترون و كورتيزول سرم در زمانهاى مختلف در هر دو مرحله

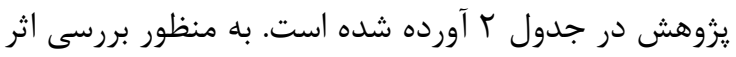

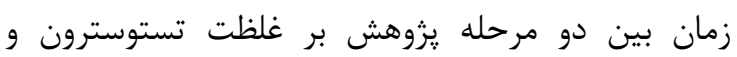
كورتيزول سرم، غلظت تستوسترون و كورتيزول سرم در ساعت 1 صبح در هر دو مرحله يزوهش با استفاده از آزمون تى زوجى با هم مقايسه شد (جدول س). نتايج نشان داد كه بين غلظت تستوسترون و كورتيزول سرم در مرحله كنترل و تجربى تفاوت معنادارى وجود نداشت. و زمان بين دو مرحله يزوهش تاثيرى بر غلظت هورمونها نداشت. به منظور بررسى اثر محروميت از خواب بر بر ياسخ تستوسترون سرم به فعاليت هوازى، بايد اثر دو متغير مستقل (تمرين و خواب) را بر يك متغير وابسته (غلظت

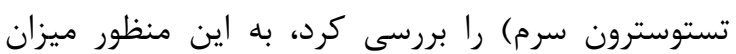
غلظت تستوسترون سرم در قبل (ساعت ^ صبح) و بعد

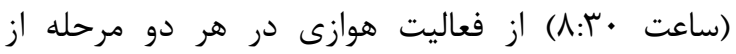

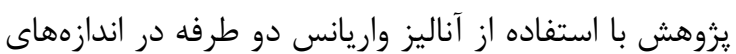
تكرارى مقايسه شد (جدول \&).

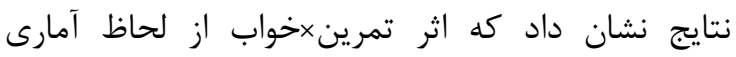
معنادار نبود (

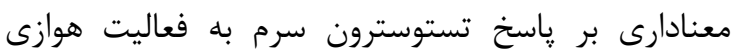

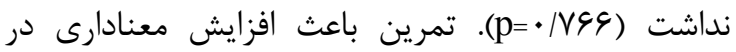

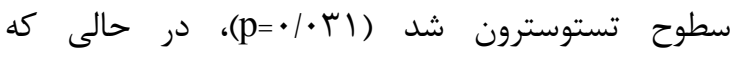

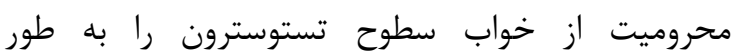

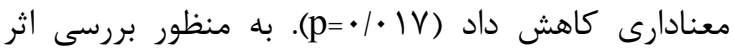
محروميت از خواب بر ياسخ كورتيزول سرم به فعاليت

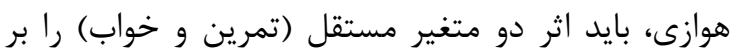
يك متغير وابسته (غلظت كورتيزول سرم) را بررسى كرد، به اين منظور ميزان غلظت كورتيزول سرم در قبل (ساعت

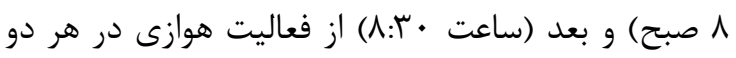

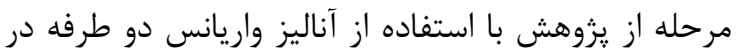
اندازههاى تكرارى مقايسه شد (جدول ه).
به طورى كه به آزمودنىها بيشنهاد شد كه به طور دلخواه، شب بين ساعت سץ تا با بخ بخوابند و صبح بين

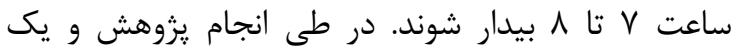

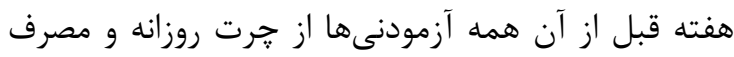

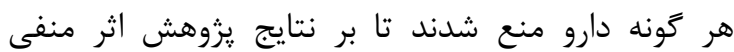
نغذارد. فعاليت هوازى به مدت ·ץ دقيقه بر روى دوجرخه كارسنج هوازى به اين صورت انجام شد كه آزمودنىها ابتدا • ا دقيقه را به عنوان كرم كردن با توان • V وات

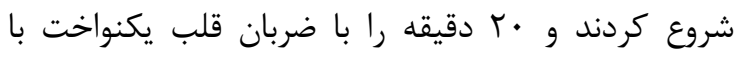

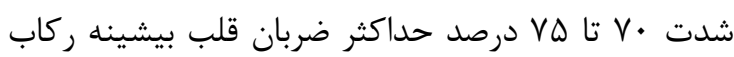
زدند. سرعت ركاب زدن در سراسر فعاليت •و دور در دقيقه بود. در سه دقيقه آخر از مرحله گرم كردن توان به

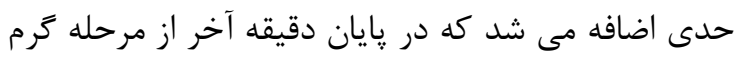

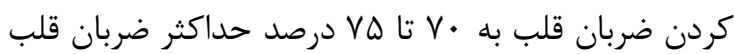

$$
\text { بيشينه برسد. }
$$

نمونه خونى از دست در حالت نشسته گرفته شد. ابتدا كارو در قسمت بالاى آرنج بسته شد و بعد از ضد عفونى آر ده

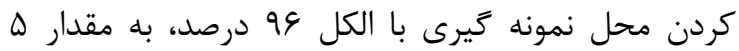

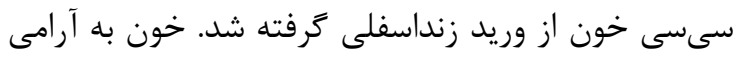
در لولههاى شيشهاى قرار داده شد و اجازه داده شد كه در لدر دماى معمولى كاملا لخته شود. بعد از لخته شدن خون، لولهها داخل دستخاه سانتريفوز با . ... دور در دقيقه به مدت ها دقيقه قرار داده شد. سرم در جههار قسمت ذخيره

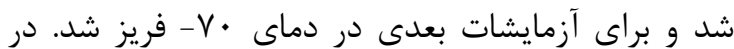
يايان يزوهش يك قسمت از سرم به آزمايشگاه انتقال داده

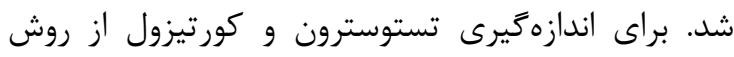
الايزا با دقت هو درصد و كيت Monobind ساخت كشور آمريكا، دستغاه Stat Fax 2100 ساخت شركت Awareness Technology با استفاده از آمار توصيفى، ميانگين و انحراف استاندارد

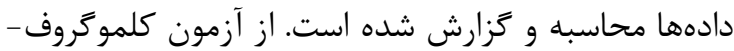
اسميرنف براى بررسى توزيع طبيعى دادهها استفاده شد.

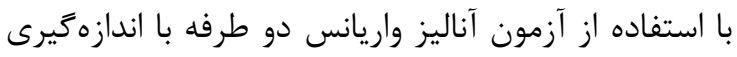
مكرر، اثر محروميت از خواب و فعاليت هوازى (دو متغير مستقل) بر غلظت تستوسترون و كورتيزول سرم (متغير وابسته) بررسى شد. از آزمون t همبسته براى مقايسه 


\begin{tabular}{|c|c|c|c|c|}
\hline • • ^ صبح & 1 صبح & ^ صبح روز قبل & & \\
\hline$\| / A V \pm T / I V Y^{c}$ & $1 \cdot / \Lambda \pm 1 / \Delta \Delta V$ & $11 / \cdot r \pm 1 / 94 \Delta$ & مرحله كنترل & \\
\hline$|r / G \cdot \pm r / F \wedge|$ & $\wedge / \wedge \Delta \mid \pm 1 / q \cdot \uparrow$ & $1 \cdot / r \mid \pm 1 / 1 r T$ & مرحله تجربى & تستوسترون \\
\hline$r \cdot|\Lambda| \pm r / \mid \cdot \Delta$ & $r \cdot|\Delta V \pm r / A V|$ & $r \cdot \mid \Lambda \varepsilon \pm r / r V \cdot$ & مرحله كنترل & \\
\hline$|\wedge / F \Delta \pm \Delta /| r \uparrow$ & $\mid \wedge / \backslash \Lambda \pm \Delta / T V V$ & $|V| \varepsilon| \pm F| \Delta \varepsilon \mid$ & مرحله تجربى & كورتيزول \\
\hline$\cdot \mid \Delta V \pm \cdot / \cdot q r$ & $\cdot \mid \Delta r \pm \cdot / \cdot \wedge r$ & $\cdot 10 \mathrm{H} \pm \cdot 1 \cdot 9 \Lambda$ & مرحله كنترل & نسبت \\
\hline$\cdot|\Delta S \pm \cdot| r T \mid$ & 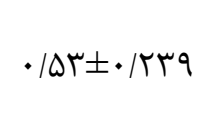 & $\cdot 194 \pm \cdot / 19$. & مرحله تجربى & كورتيزول \\
\hline
\end{tabular}

جدول سا: آزمون تى زوجى بررسى اثر زمان بين دو مرحله يزوهش بر غلظت تستوسترون (نانوكرم/ميلى ليتر) و كورتيزول سرم (ميكرو گرم/دسى ليتر)

\begin{tabular}{|c|c|c|c|c|}
\hline سطح معنادارى: p & t مشاهده شده t & ساعت ^ مرحله تجربى & ساعت ^ مرحله كنترل & \\
\hline .1110 & $1 / V \& \Delta$ & $1 \cdot / r \mid \pm 1 / 1 \pi r$ & $11 / \cdot r \pm 1 / 94 \Delta$ & تستوسترون \\
\hline$\cdot 1 \cdot \mathrm{Vr}$ & $T / \cdot T \Lambda$ & $|V| q| \pm \psi / \Delta Q|$ & $r \cdot \mid \Lambda \& \pm T / T V$. & كورتيزول \\
\hline
\end{tabular}

جدول fا: تجزيه و تحليل واريانس دو طرفه با اندازهاى مكرر براى تغييرات غلظت تستوسترون

\begin{tabular}{|c|c|c|}
\hline P: سطح معنادارى & F مشاهده شده F & \\
\hline$\cdot / \cdot r 1$ & $9 \mid 011$ & تمرين \\
\hline $.1 .1 \mathrm{~V}$ & N/4q & خواب \\
\hline - /V\&4 & .1 .94 & خواب × تمرين \\
\hline
\end{tabular}

جدول ه: تجزيه و تحليل واريانس دو طرفه با اندازهاى مكرر براى تغييرات غلظت كورتيزول

\begin{tabular}{|c|c|c|}
\hline P: سطح معنادارى & F مشاهده شده F & \\
\hline . krq & $1 / 019$ & تمرين \\
\hline . & 1/4TE & خواب \\
\hline .1949 & $.1 \cdot r$ & خواب × تمرين \\
\hline
\end{tabular}

جدول ع: تجزيه و تحليل واريانس دو طرفه با اندازهاى مكرر براى تغييرات نسبت تستوسترون به كورتيزول

\begin{tabular}{|c|c|c|}
\hline سطح معنادارى:P & F مشاهده شده F مشه & \\
\hline .1 .94 & $F / \Delta / \Lambda$ & تمرين \\
\hline$\cdot / 999$ & $\cdot 1 \cdot \cdot 1$ & خواب \\
\hline ./VTV & . / r. & خواب × تمرين \\
\hline
\end{tabular}


فعاليت هوازى تاثير معنادارى ندارد، امرى نامعلوم است كه نياز به مطالعات بيشترى دارد. در اين يزوهش مشاهده شد كه ·r دقيقه فعاليت هوازى زير بيشينه بر روى دوجرخه كارسنج موجب افزايش معنادارى در غلظت تستوسترون سرم شد. كه در اين دورين رابطه يافتههاى تحقيق حاضر با نتايج مطالعات عطارزاده

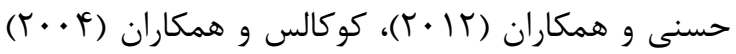

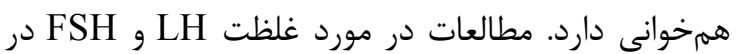

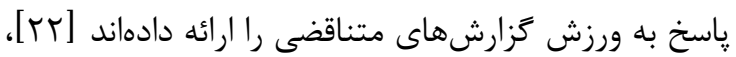
و از طرفى ياسخ تستوسترون به ورزش خيلى سريعتر از

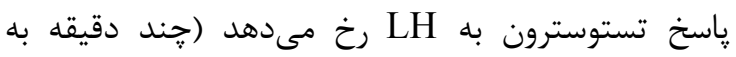
فعاليت شديد و • r تا • ب دقيقه به LH)، معمولاً يذيرفته شده كه ورزش با مكانيسمهايى غير از اثر LH سبب افزايش تستوسترون يلاسما مىشود [9]. برخى مكانيسهم-

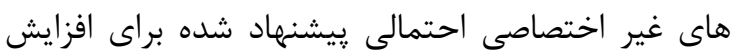

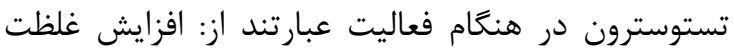
خون ناشى از فعاليت ورزشى با كاهش حجم يلاسما و كاهش ميزان تجزيه هورمونهاى جنسى. تستوسترون در كبد برداشت و تجزيه مىشود، افزايش تستوسترون سرم هنگَام فعاليت هوازى مىتواند به علت كاهش جريان خون كبدى هنعام فعاليت باشد [سr]. اين احتمال وجود هواليت دارد كه تحريك سمياتيكى يا كاتكولامينهاى موجود در خون علت افزايش غلظت يلاسمايى تستوسترون هنگَام فعاليت بدنى باشند. اين موضوعى است كه مطالعات درباره آن

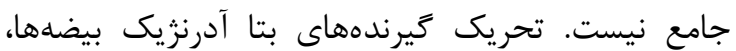
سنتز و رهايش تستوسترون را تحريك مى كند. غلظت يلاسمايى تستوسترون و كاتكولامينها متناسب با افزايش شدت فعاليت ورزشى افزايش مىيابند. اين موضوع از اين

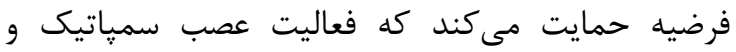
ترشح كاتكولامينها، ترشح تستوسترون هنغام فعاليت ورزشى كوتاه مدت را تحريك مى كند [a].

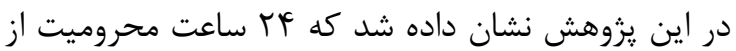
خواب موجب كاهش معنادارى در غلظت تستوسترون سرم شد. اين نتيجه با نتايج مطالعات وو و همكاران (1) (1) (Y)،

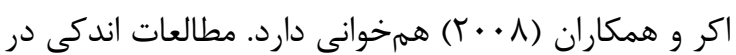
زمينه تاثير محروميت از خواب بر غلظت آندروزنها همات صورت گرفته كه كاهش آندروزنها از جمله تستوسترون در اثر
نتايج نشان داد كه اثر تمرين×خواب از لحاظ آمارى

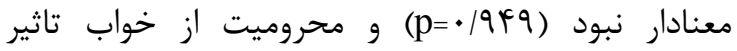
معنادارى بر ياسخ كورتيزول سرم به فعاليت هوازى نداشت

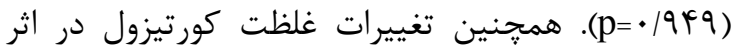
تمرين (qسץ/• لحاظ آمارى معنادار نبود. به منظور بررسى اثر محروميت از خواب بر ياسخ نسبت تستوسترون به كورتيزول به فعاليت هوازى، بايد اثر دو متغير مستقل (تمرين و خواب) را بر يك متغير وابسته (نسبت تستوسترون به كورتيزول) را بررسى كرد، به اين

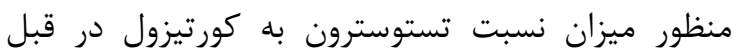

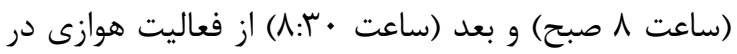
هر دو مرحله از يزوهش با استفاده از آناليز واريانس دو بعد

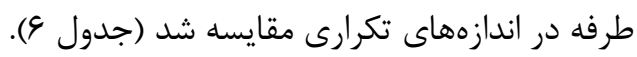

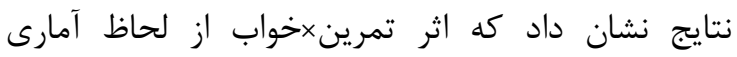
معنادار نبود (p=/NY ) و محروميت از خواب تاثير معنادارى بر پاسخ نسبت تستوسترون به كورتيزول به

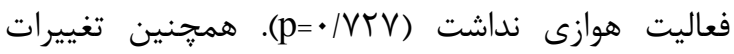

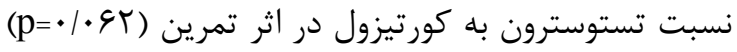

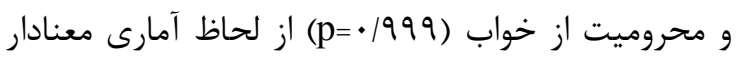
نبود. بحث تا آن جايى كه امكان بررسى و جستجوى ادبيات ريشين بوده است، هيج مطالعهاى تاثير محروميت از خواب بر

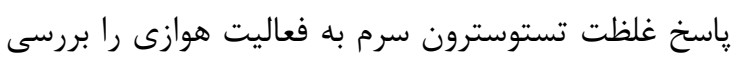
نكرده است. در يروهش حاضر كه به بررسى اين امر يرداخته است، مشاهده شده است كه محروميت از خواب تاثير معنادارى بر ياسخ غلظت تستوسترون سرم به فعاليت

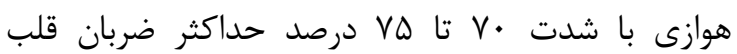
نداشت. از طرف ديخر، محروميت از خواب سبب كاهش غلظت تستوسترون سرم شد و همجنين · ب دقيقه فعاليت

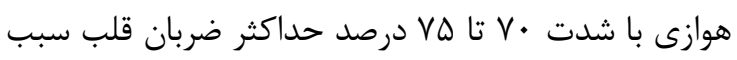
افزايش معنادارى بر غلظت تستوسترون سرم شد. و بدون تاثير بودن محروميت از خواب بر غلظت تستوسترون سرم

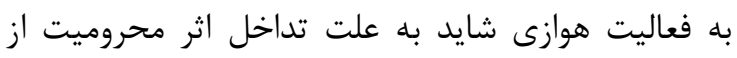
خواب و فعاليت هوازى باشد. با اين حال، اين كه جِكونه محروميت از خواب بر ياسخ غلظت تستوسترون سرم به به به 
فعاليت بدنى متناسب با شدت تمرين باعث افزايش ترشح

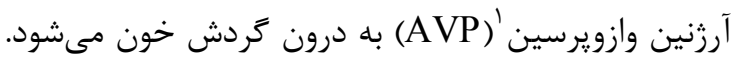
ترشح ACTH و AVP در طى ورزش به طور هماهنگى رخ مىدهد. يكى از مكانيسم هايى كه سبب افزايش فعاليت محور HPA مىشود، افزايش سطوح لاكتات يلاسما است. هورمون آنزيوتانسيون II و اينترلوكينها كه در طى ورزش افزايش مىيابند مىتوانند محور فعال كنند [11]]. هنغام فعاليت ارسال ييام از عضلات فعال از طريق عصب آوران براى فعال شدن محور فمرسيام ضرورى است. يُامهاى ارسالى از عضلات فعال و تغييرات

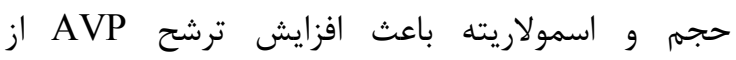
هييوتالاموس در هنَام فعاليت بدنى مىشود، كه سبب افزايش ترشح ACTH در هيبيوفيز قدامى مىشود. هورمون ACTH هم به نوبه خود ترشح كورتيزول را از قشر غدد فوق كليوى افزايش مى هوهد [rV]

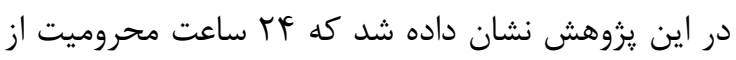
خواب تاثير معنادارى در غلظت كورتيزول سرم نداشت.

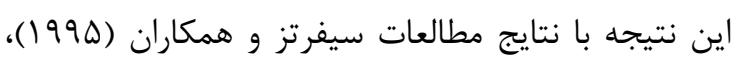

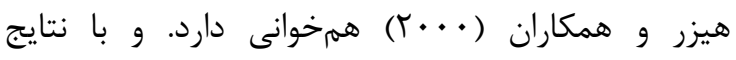

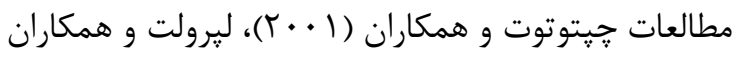
ناهمخوان است. علت ناهمخوانى نتايج يزوهش (199V) حاضر با برخى يزوهشها مىتواند دلايلى از جمله نوع

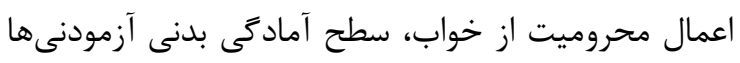
و عوامل محيطى از جمله نور و دما محيط در هنغام محروميت از خواب باشد. اختلاف در غلظت كورتيزول در اثر محروميت از خواب مىتواند به دليل كنترل نكردن

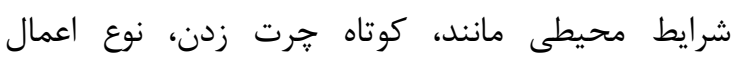

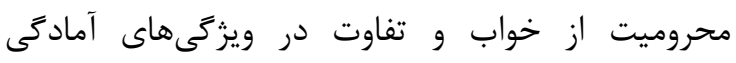
جسمانى و ميزان فعاليت بدنى آزمودنى ها دارد. همرِنين مىتوان كفت كه در اوايل ساعات محروميت از خواب

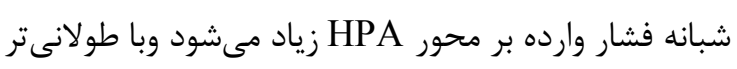
شدن محروميت از خواب فشار وارده بر محور

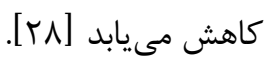
نتيجه كيرى با توجه به يافتههاى يزوهش حاضر مىتوان كفت يكى

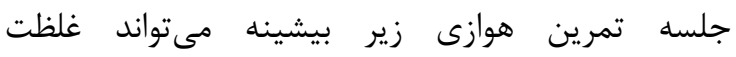

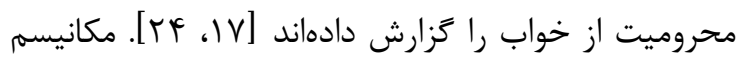
تاثير محروميت از خواب بر كاهش غلظت تستوسترون به روشنى مشخص نيست، عملكرد بيضdها به وسيله بعضى مترو نوروترانسميتورها از جمله سروتونين تنظيم مىشود. نشان

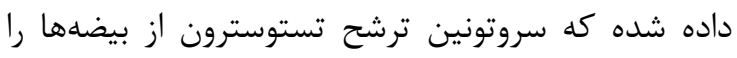

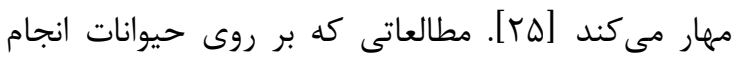
شده گزارش دادهاند كه محروميت از خواب موجب افزايش

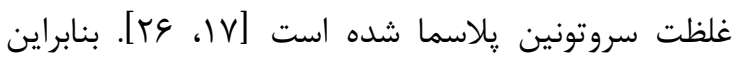
كاهش غلظت تستوسترون در اثر محروميت از خواب مى تواند به دليل افزايش غلظت سروتونين در اثر محروميت از

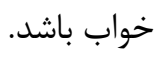
در ״زوهش حاضر كه به بررسى اين امر زيرداخته است،

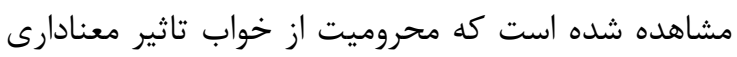
بر ياسخ غلظت كورتيزول سرم به فعاليت هوازى با شدت اته

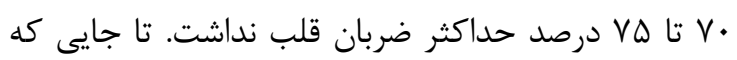
ما بررسى كرديم، هيج مطالعهاى تاثير محروميت از خواب

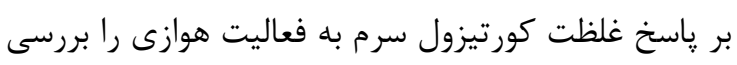

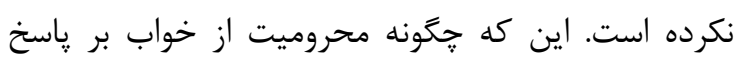
غلظت كورتيزول سرم به فعاليت هوازى تاثير معنادارى ندارد، امرى نامعلوم است كه نياز به مطالعات بيشترى دارد. در اين يزوهش مشاهده شد كه ·r دقيقه فعاليت هوازى

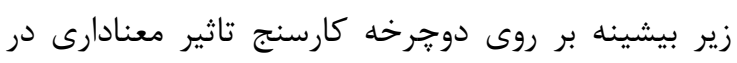

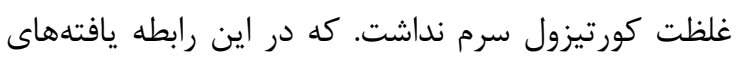

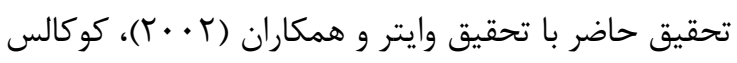

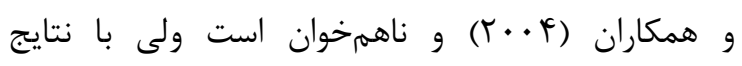

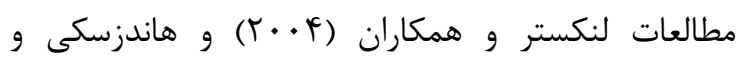

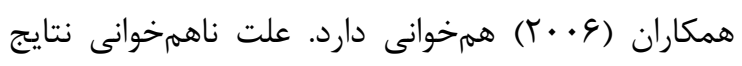
برخى مطالعات با يافتههاى يروهش حاضر مى تواند دلايل

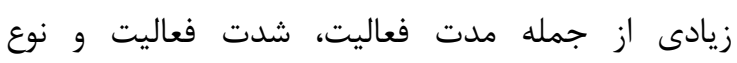
آزمودنىها باشد. در مطالعه وايتر شدت فعاليت هوازى ماليت، درصد حداكثر اكسيزن مصرفى بود در حالى كه در مطالعه

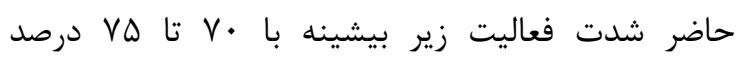
حداكثر ضربان قلب بود. در مطالعات لنكستر، هاندزسكى شدت فعاليت زير بيشينه بود.

1 - Arginine vasopressin 
اسلامى واحد بروجرد با عنوان اثر محروميت از خواب بر

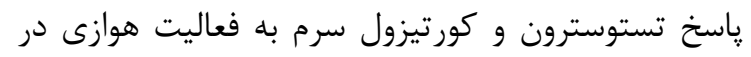

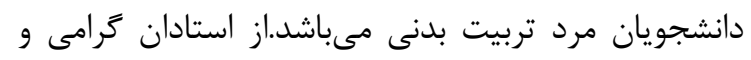

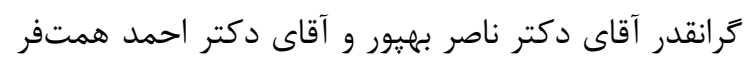

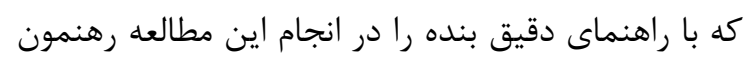

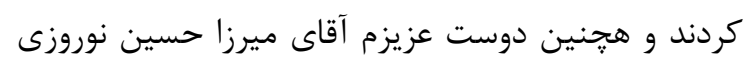

كمره كه از هيج كمكى دريغ نكردند و همه دانشجويان دمبن

عزيزى كه به عنوان آزمودنى در اين مطالعه شركت كردند،

$$
\text { كمال تشكر و قدردانى را دارم. }
$$

\section{References}

1. Alhola P, Polo-Kantola P. (2007), Sleep deprivation: Impact on cognitive performance, Neuropsychiatric Disease and Treatment, 3(5): p. 553-567.

2. Sforza E, Chapotot F, Lavoie S, Roche F, Pigeau R, Buguet A, Heart rate activation during spontaneous arousals from sleep: effct of sleep deprivation. Clin Neurophysiol, 2004; 115(11): 2442-2451.

3. McMorris $\mathrm{T}$, Harris RC, Howard AN, Langridge G, Hall B, Corbett J, Dicks M, Hodgson C, Creatine supplementation, sleep deprivation, cortisol, melatonin and behavior, Physiol Behav, 2007; 90(1): 21-28.

4. Souissi N, Sesboue B, Gauthier A, Larue J, Davenne D, Effects of one night's sleep deprivation onanaerobic performance the following day, Eur J Appl Physiol, 2003; 89: 359-366.

5. Hui L, Hua F, Diandong H, Hong Y, (2007), Effects of sleep and sleep deprivation on immunoglobulins and complement in humans. Brain, Behavior and Immunity, 2007; 21: 308-310.

6. Vardar SA, Öztürk L, Kurt C, Bulut E, Sut N, Vardar E, Sleep deprivation induced anxiety and anaerobic performance, Journal of Sports Science and Medicine, 2007; 6: 532-537.

7. Fredrick D. Optimize Your Training off the Bike, Velo News, 2005; 34(7).

8. Shakeri N, Nikbakht H, Azarbayjani MA, Amirtash AM, The effect of different types of exercise on the testosterone/cortisol ratio in untrained young males. Annals of Biological Research, 2012; 3(3):1452-1460[Persian]

$$
\begin{aligned}
& \text { تستوسرون سرم را به طور معنادارى افزايش دهد، در حالى }
\end{aligned}
$$

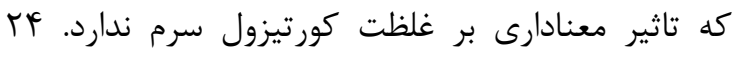

$$
\begin{aligned}
& \text { ساعت محروميت از خواب سبب كاهش معنادارى در } \\
& \text { غلظت تستوسترون سرم مىشود، اما در غلظت كورتيزول }
\end{aligned}
$$

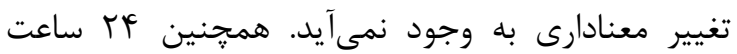

$$
\begin{aligned}
& \text { محروميت از خواب تاثير معنادارى بر غلظت تستوسترون و } \\
& \text { كورتيزول سرم به فعاليت هوازى زير بيشينه ندارد. } \\
& \text { تشكر و قدردانى توري } \\
& \text { اين مقاله برگرفته از يايان نامه آقاى محمدرضا رئيسى } \\
& \text { دانشجوى كارشناسى ارشد فيزيولوزى ورزشى دانشعاه آزاد }
\end{aligned}
$$

9. Warren MP, Constantini NW, Sports Endocrinology, Humana Press, Totowa, New Jersey, 2000; 43-55

10. Attarzadeh Hosseini SR, Vadood M, Hejazi $\mathrm{K}$, Investigation of the salivary cortisol and testosterone during Futsal game, International Journal of Sport Studies, 2012; 2(6): 295301[Persian]

11. Wittert GA, Stewart DE, Graves MP, "et al", Plasma corticotrophin releasing factor and vasopressin responses to exercise in normal man, Clin Endocrinol Oxford, 1991; 35:311317.

12. Kokalas N, Tsalis G, Tsigilis N, Mougios $\mathrm{V}$, Hormonal responses to three training protocols in rowing, Eur J Appl Physiol, 2004; 92: 128-132.

13. Lancaster GI, Halson SL, Khan Q, Drysdale P, Wallace F, Jeukendrup AE, Drayson MT, Gleeson M. Effects of acute exhaustive exercise and chronic exercise training on type 1 and type $2 \mathrm{~T}$ lymphocytes, Exerc Immunol Rev, 2004; 10: 91-106.

14. Handziski Z, Maleska V, Petrovska S, Nikolik S, Mickoska E, Dalip M, Kostova $\mathrm{E}$, The changes of ACTH, cortisol, testosterone and testosterone/cortisol ratio in professional soccer players during a competition halfseason, Bratisl Lek Listy, 2006; 107(6-7):259263.

15. Judd HL, Parker DC, Yen SS, Sleep-Wake Patterns Of Lh And Testosterone Release In Prepubertal Boys, J Clin Endocrinol Metab, 1977; 44(5):865-9.

16. Schiavi RC, Davis DM, Fogel M, White D, Edwards A, Igel G, Szechter R, Fisher C. Luteinizing hormone and testosterone during 
nocturnal sleep: relation to penile tumescent cycles, Arch Sex Behav, 1977; 6(2):97-104.

17. Wu JL, Wu RS, Yang JG, Huang CC, Chen KB, Fang KH, Tsai HD, Effects of sleep deprivation on serum testosterone concentrations in the rat, Neuroscience Letters, 2011; 494:124-129.

18. Chapotot F, Buguet A, Gronfier C, Brandenberger G, Hypothalamo-pituitaryadrenal axis activity is related to the level of central arousal: effect of sleep deprivation on the association of high-frequency waking electroencephalogram with cortisol release, Neuroendocrinology, 2001; 73(5), 312-321.

19. Leproult R, Copinschi G, Buxton O, Van Cauter E, Sleep loss results in an elevation of cortisol levels the next Evening, Sleep, 1977; 20(10):865-870.

20. Seifritz E, Hemmeter U, Trachsel L, "et al", Effects of flumazenil on recovery sleep and hormonal secretion after sleep deprivation in male controls, Psychopharmacology, 1995; 120(4):449-456.

21. Heiser P, Dickhaus B, Schreiber W, Clement HW, Hasse C, Hennig J, Remschmidt H, Krieg JC, Wesemann W, Opper C, White blood cells and cortisol after sleep deprivation and recovery sleep in humans, Eur Arch Psychiatry Clin Neurosci, 2000; 250: 16-23.

22. Safarinejad MR, Azma K, Kolahi AA, The effects of intensive, long-term treadmill running on reproductive hormones, hypothalamus- pituitary-testis axis, and semen quality: a randomized controlled study, J Endocrinol, 2009; 200(3):259-271[Persian]
23. Baker JR, Bemben MG, Anderson MA, Bemben DA, Effects of age on testosterone responses to resistance exercise and musculoskeletal variables in men, J Strength Cond Res, 2006; 20(4):874-881.

24. Eacker SM, Agrawal N, Qian K, Dichek HL, Gong EY, Lee K, Braun RE, Hormonal Regulation of Testicular Steroid and Cholesterol Homeostasis, Mol Endocrinol, 2008; 22(3):623-635.

25. Frungieri MB, Zitta K, Pignataro OP, Gonzalez-Calvar SI, Calandra RS, Interactions between testicular serotoninergic, catecholaminergic, and corticotropin-releasing hormone systems modulating cAMP and testosterone production in the golden hamster, Neuroendocrinology, 2002; 76:35-46.

26. Meerlo P, Sgoifo A, Suchecki D, Restricted and disrupted sleep: effects on autonomic function, neuroendocrine stress systems and stress responsivity, Sleep Med. Rev, 2008; 12:197-210.

27. Hew-Butler T, Jordaan E, Stuempfle KJ, Speedy DB, Siegel AJ, Noakes TD, Soldin SJ, Verbalis JG, Osmotic and Nonosmotic Regulation of Arginine Vasopressin during Prolonged Endurance Exercise, J Clin Endocrinol Metab, 2008; 93(6):2072-2078.

28. Balbo M, Leproult R, Van Cauter E, Impact of Sleep and Its Disturbances on HypothalamoPituitary-Adrenal Axis Activity, International Journal of Endocrinology, 2010; Article ID 759234, 16 pages. 
Original Article

\title{
Effects of sleep deprivation on serum testosterone and cortisol response followed aerobic activity
}

\author{
Raeesi M.R ${ }^{l}$, Behpoor $N^{2}$, Hematfar $A^{3}$, Norouzi Kamareh M. $H^{4^{*}}$ \\ ${ }^{1}$ Master of Exercise Physiology, Islamic Azad University Broujerd Branch, Broujerd, Iran \\ ${ }^{2}$ Assistant professor of Exercise Physiology, Department of Physical Education and Sport Sciences, Razi \\ University, Kermanshah, Iran \\ ${ }^{3}$ Assistant professor of Exercise Physiology, Islamic Azad University Broujerd Branch, Broujerd, Iran \\ ${ }^{4}$ Master of Exercise Physiology, Department of Physical Education and Sport Sciences, Razi University, \\ Kermanshah, Iran
}

*Corresponding Author:

Department of Physical

Education and Sport Sciences,

Razi University, Kermanshah, Iran

Email:

mirzahoseynnorozi@yahoo.co $\mathrm{m}$

\begin{abstract}
Background \& objectives: Sleep is restorative process for the nervous system. There are many situations in which sleep is disturbed prior to an athletic event. However, the effect of sleep deprivation on physiological body function in response to exercise remains unknown. The aim of this study was to investigate the effects of sleep deprivation on serum testosterone and cortisol response followed aerobic activity.

Materials and Methods: 10 male physical education students were voluntarily participated in this quasi-experimental study. Study was prformed in two separate occasions; control and experimental within two weeks. In the cotrol occasion, normal sleep and aerobic activity and in the experimental occasion, sleep deprivation and aerobic activity was applied. Aerobic activity was performed on bicycle ergometer for 30 minutes at intensity of 70 to 75 percent of maximum heart rate. Changes in serum testosterone and cortisol concentrations in before and after aerobic activity in both occasions were analyzed by the two repeated measures ANOVA using spss software.
\end{abstract}

Results: The results showed that sleep deprivation has no significant effect on serum levels of testosterone $(p=0.766)$ and cortisol $(p=0.949)$ followed aerobic activity.

Conclusion: Sleep deprivation does not affect serum levels of testosterone and cortisol followed sub maximal aerobic activity.

Keywords: Sleep deprivation, aerobic activity, testosterone, cortisol

Submitted:3 Feb 2013

Revised:13 Mar 2013

Accepted:11 June 2013 